\title{
Determinants of Efficient Health Commodity Management in Maternal Child Health: A Case of Meru County, Kenya
}

\author{
Elvis Mwandawiro Mbatia ${ }^{1 *}$, Eunice Muthoni Mwangi ${ }^{1}$, Wanja Mwaura-Tenambergen ${ }^{1}$ \\ ${ }^{1}$ Department of Health Systems Management, Kenya Methodist University \\ DOI: 10.29322/IJSRP.11.08.2021.p11654 \\ http://dx.doi.org/10.29322/IJSRP.11.08.2021.p11654
}

\begin{abstract}
Emergency Obstetric and Neonatal Care (EmONC) has become a priority especially in developing countries like Kenya. However, access to obstetric and neonatal care has been hindered by lack of medical commodity, equipment's and vaccines related to Maternal Child Health (MCH), resulting to high maternal and neonatal mortality rates. The study is anchored in the health products, vaccines and technologies pillar of a health system. The study seeks to establish the determinants of an efficient health commodity management in $\mathrm{MCH}$ in public health facilities in Meru County. Specific objectives were to establish the influence of i) logistic management information system, ii) medical staff competency, iii) inventory management, and iv) supply chain management practices on efficient health commodity management in maternal child health in Meru County. The study adopted a cross-sectional design with quantitative methods for data collection. The study sample was 116 health care workers from all public health facilities in Meru County. Results indicated that logistic management information system was positively and significantly associated with the efficient health commodity management in $\mathrm{MCH}\left(\chi^{2}=4.450, P=0.035\right)$. This implied that LMIS had a positive and significant association influence on the efficient management of health commodity in MCH services. Medical staff competency was positively and significantly associated with the efficient health commodity management of $\operatorname{MCH}\left(\chi^{2}=7.0489, P=0.008\right)$. The study recommends the County Health Department of Meru should i) invest in health information systems for quantification, forecasting reporting and procurement of medical goods and equipment; ii) conduct continuous professional education among health workers to ensure efficient management of healthcare commodities in the health facilities.
\end{abstract}

Index Terms- Efficient Health commodity management, logistic management information system, Staff competency, Inventory management, Procurement management practices.

\section{INTRODUCTION}

W HO, 2014 reports infer that Medicines as a pillar of health and must have certain characteristics that include appropriate use, universal access to all, affordable cost and should always focus on health system strengthening across facilities, organizations and systems. The Kenya Demographic and Health Survey (KDHS) 2014 reports that the increased Kenya mother and
Child mortality rates which stands at 362/100,000 live births its major contributing factors lies to poorly managed commodities and health care delivery and little access to Reproductive maternal child health care services. Pastakia et al., (2018) stated that a reliable and efficient healthcare management system is dependent on having work force that has technical and administrative skills and experience and capacity to man it effectively.

Workforce challenges stretch an already overworked health system and reduces the opportunities to improve interventions that are needed to develop efficient health care system including an efficient logistic management system. Desale et al., (2013) noted that, in spite of the existence of a well-designed laboratory management information system (LMIS), the quality of reports generated from Daily Activity Register and stock cards were very low. As a consequence of this there were regular stock outs of key commodities in many health facilities" A study by Bray and Awuah, (2019), showed that inventory management is important facet to commodity management, since systems of the inventory that are poorly maintained will lead to a negative impact that will severely affect the optimal delivery of service.

The broad objective of the study was to explore the determinants of an efficient health commodity management in maternal child health in government health facilities in Meru County. The specific objectives were to establish the influence of i) logistic management information system, ii) medical staff competency, iii) inventory management, and iv) supply chain management practices on efficient health commodity management in maternal child health in Meru County.

\section{METHODS}

The study adopted a cross-sectional study design. The study was carried out in 51 Government facilities implementing the Emergency Obstetric and Neonatal Care (EmONC) in Meru County. The target population of 116 health workers The study sample was 90 participants which was reached using Yamane, (1967) formula, they included: 30 Clinical officers, 48 Nurses and 12 Pharmaceutical Technologists 9, and Pharmacists 3. Ethical clearance was sought from the Kenya Methodist University Science, Research and Ethics Committee, and informed consent from the study participants. Quantitative data was collected using a structured questionnaire and analyzed by SPSS. The test statistics used were P-values, Pearson's Rho and the significance 
level was set at 0.05 . For inferential statistics the model used was: $\mathrm{Y}=f\left(X_{1}, X_{2}, X_{3} X_{4}\right)+\varepsilon$.

\section{RESULTS}

Study results indicated that most of the respondents were male 52(58\%) and 55(61\%) were aged between 31-45 years.
Nearly half $38(42 \%)$ of the respondents were from Tier 2 health facilities and the least $12(13 \%)$ were from Tier 4 facilities. More than half $54(60 \%)$ of the respondents had 5-10 years' work experience while 12(13\%) had less than 5 years of work experience. Most of the study respondents were nurses 48(53\%), followed general clinical officer at 30(33\%). See Table 1.

Table 1: Socio-demographic characteristics of respondents

\begin{tabular}{lll}
\hline Gender & Frequency & Percentage \\
\hline Male & 52 & 58 \\
Female & 38 & 42 \\
Age & 19 & \\
30 years and below & 55 & 21 \\
31-45 years & 16 & 18 \\
Above 46 years & & \\
Tier of the health facility & 17 & 19 \\
Tier 1 & 38 & 42 \\
Tier 2 & 23 & 26 \\
Tier 3 & 12 & 13 \\
Tier 4 & & \\
Working Experience & 12 & 13 \\
Less than 5 years & 54 & 60 \\
6 -10 years & 24 & 27 \\
11 -15 years & & \\
Cadre of Staff & 30 & 33 \\
General Clinical Officer & 48 & 53 \\
Nurse & 3 & 3 \\
Pharmacist & 9 & 10 \\
Pharmaceutical Technologist & &
\end{tabular}

The study sought information on Logistic Management Information Systems (See Table 2). The respondents agreed that commodity financing affect commodity management and service delivery sustainability (Mean, 3.81) and that facility health management team have quality assurance quality improvement team to check on drug quality, safety, and pharmacovigilance for health commodities (Mean, 4.24). However, they disagreed that the facility has LMIS to report on health commodities in Mother Child Health $(\mathrm{MCH})($ Mean 2.51) and that LMIS affects availability of EMONC commodity in this facility (Mean, 2.16).

Table 2: Responses on Logistic Management Information Systems

\begin{tabular}{|c|c|c|c|c|c|c|c|}
\hline \multirow[t]{2}{*}{ Item } & \multicolumn{5}{|c|}{ Responses } & \multirow[t]{2}{*}{ Mean } & \multirow[t]{2}{*}{ SD } \\
\hline & $\begin{array}{l}\text { SA } \\
\mathbf{N}(\%)\end{array}$ & $\begin{array}{l}\mathbf{A} \\
\mathbf{N}(\%)\end{array}$ & $\begin{array}{l}\mathbf{N} \\
\mathbf{N}(\%)\end{array}$ & $\begin{array}{l}\text { D } \\
\mathrm{N}(\%)\end{array}$ & $\begin{array}{l}\text { SD } \\
\mathbf{N}(\%)\end{array}$ & & \\
\hline $\begin{array}{l}\text { The facility has LMIS to report on health } \\
\text { commodities in } \mathrm{MCH} \text {. }\end{array}$ & 11(12) & 17(19) & $5(6)$ & $31(34)$ & $26(29)$ & 2.51 & 2.39 \\
\hline $\begin{array}{l}\text { Logistic Management and Information System } \\
\text { affects availability of EMONC commodity in this } \\
\text { facility. }\end{array}$ & $6(7)$ & $12(113)$ & $7(8)$ & $30(33)$ & $35(39)$ & 2.16 & 2.02 \\
\hline $\begin{array}{l}\text { Commodity financing affect commodity } \\
\text { management and service delivery sustainability in } \\
\text { MCH clinic in this facility. }\end{array}$ & $28(31)$ & $39(43)$ & $6(7)$ & $12(13)$ & $5(6)$ & 3.81 & 3.48 \\
\hline $\begin{array}{l}\text { Facility health management team have quality } \\
\text { assurance quality improvement team to check on }\end{array}$ & $49(54)$ & $28(31)$ & $6(7)$ & $0(0.0)$ & $7(8)$ & 4.24 & 3.88 \\
\hline
\end{tabular}


drug quality, safety, and pharmacovigilance for

Health Commodities in $\mathrm{MCH}$.

Facility use LMIS for routine ordering of drugs for $\quad 27(30) \quad 27(30) \quad 10(11) \quad 15(17) \quad 11(12)$ health commodities for maternal child health.

Key: $S A=$ Strongly agreed, $A=$ Agreed, $N=$ Neutral, $D=$ Disagreed, $S D=$ Strongly Disagreed

On medical staff competency, the research found that most of the respondents agreed that trainings and mentorship on efficient commodity management affect EMONC commodity and supplies in the facility (Mean, 3.98), staff working in MCH or Pharmacy had been trained on commodity management in relation to EMONC services (Mean, 3.71) and that supportive supervision or mentorship on commodity management in relation to EMONC services had been done in their facility (Mean, 4.19). See Table 3

Table 3: Respondents on Medical Staff Competency

\begin{tabular}{|c|c|c|c|c|c|c|c|}
\hline \multirow[t]{2}{*}{ Statement } & \multicolumn{5}{|c|}{ Responses } & \multirow[t]{2}{*}{ Mean } & \multirow{2}{*}{$\begin{array}{l}\text { Std. } \\
\text { Dev. }\end{array}$} \\
\hline & $\begin{array}{l}\text { SA } \\
\mathbf{N}(\%)\end{array}$ & $\begin{array}{l}\mathbf{A} \\
\mathbf{N}(\%)\end{array}$ & $\begin{array}{l}\mathbf{N} \\
\mathbf{N}(\%)\end{array}$ & $\begin{array}{l}\mathrm{D} \\
\mathrm{N}(\%)\end{array}$ & $\begin{array}{l}\text { SD } \\
\mathbf{N}(\%)\end{array}$ & & \\
\hline $\begin{array}{l}\text { Trainings and mentorship on efficient commodity } \\
\text { management affect EMONC commodity and } \\
\text { supplies in this facility. }\end{array}$ & $44(49)$ & $23(26)$ & $5(6)$ & $13(14)$ & $5(6)$ & 3.98 & 3.67 \\
\hline $\begin{array}{l}\text { Staff working in MCH / pharmacy have been } \\
\text { trained on Commodity management in relation to } \\
\text { EMONC Services. }\end{array}$ & $25(28)$ & $40(44)$ & $6(7)$ & $12(13)$ & $7(8)$ & 3.71 & 3.40 \\
\hline $\begin{array}{l}\text { Supportive supervision or mentorship on } \\
\text { commodity management in relation to EMONC } \\
\text { services in this facility. }\end{array}$ & $47(52)$ & $27(30)$ & $6(7)$ & $6(7)$ & $4(4)$ & 4.19 & 3.82 \\
\hline
\end{tabular}

Key: $S A=$ Strongly agreed, $A=$ Agreed, $N=$ Neutral, $D=$ Disagreed, $S D=$ Strongly Disagreed

With regard to inventory management, most respondents agreed that the inventory management affects efficient health commodity management in child health in Meru County (Mean, 4.17) that the facility have a proper inventory, storage and distribution system in place for health commodity in child health services (Mean, 4.00), and that the facility have properly filled daily activity registers and bin cards available in the facility for inventory management for EMONC drugs and commodity (Mean, 3.84). See Table 4. They also observed that its critical to maintain and keep inventory for efficient and optimal commodity management system.

Table 4: Responses on Inventory Management

\begin{tabular}{|c|c|c|c|c|c|c|c|}
\hline \multirow[t]{2}{*}{ Item } & \multicolumn{5}{|c|}{ Responses } & \multirow[t]{2}{*}{ Mean } & \multirow{2}{*}{$\begin{array}{l}\text { Std. } \\
\text { Dev }\end{array}$} \\
\hline & $\begin{array}{l}\text { SA } \\
\mathbf{N}(\%)\end{array}$ & $\begin{array}{l}\mathrm{A} \\
\mathbf{N}(\%)\end{array}$ & $\begin{array}{l}\mathbf{N} \\
\mathbf{N}(\%)\end{array}$ & $\begin{array}{l}\mathbf{D} \\
\mathbf{N}(\%)\end{array}$ & $\begin{array}{l}\text { SD } \\
\mathbf{N}(\%)\end{array}$ & & \\
\hline $\begin{array}{l}\text { Inventory management affects efficient Health } \\
\text { Commodity Management in Child Health in } \\
\text { Meru County. }\end{array}$ & $38(42)$ & $38(42)$ & $7(8)$ & $5(6)$ & $2(2)$ & 4.17 & 3.75 \\
\hline $\begin{array}{l}\text { The facility have a proper inventory, storage and } \\
\text { distribution system in place for Health } \\
\text { Commodity in Child health services. }\end{array}$ & $32(36)$ & $42(47)$ & $5(6)$ & $6(7)$ & $5(6)$ & 4.00 & 3.63 \\
\hline $\begin{array}{l}\text { The Facility have properly filled daily activity } \\
\text { registers and bin cards available in the facility } \\
\text { for inventory management for EMONC Drugs } \\
\text { and Commodity. }\end{array}$ & $29(32)$ & $38(42)$ & $8(9)$ & $10(11)$ & $5(6)$ & 3.84 & 3.50 \\
\hline $\begin{array}{l}\text { The facility performs inventory internal control } \\
\text { of health commodity (use of purchase order for }\end{array}$ & $39(43)$ & $26(29)$ & $9(10)$ & $11(12)$ & $5(6)$ & 3.92 & 3.60 \\
\hline
\end{tabular}


tracking, inventory ledger or physical inventory

counts verses recorded amounts).

The stock status level available for the

following EMONC commodity and

$27(30) \quad 38(42) \quad 9(10) \quad 12(13) \quad 4(4) \quad 3.80$

3.45

equipment's in the $\mathrm{MCH}$ are readily available.

Key: $S A=$ Strongly agreed, $A=$ Agreed, $N=$ Neutral, $D=$ Disagreed, $S D=$ Strongly Disagreed

Study results revealed that most respondents agreed that supply chain practices influenced the efficiency of health commodity management (see Table 5). More than half of the respondents agreed that supply chain practices (selection, procurement, distribution and storage) influence EMONC commodity in $\mathrm{MCH}$ in this facility (Mean, 3.88); they have procurement method of health commodity related to EMONC services in this facility (Mean, 3.78), and that facility have Policy, guideline and Job aids on Procurement, storage, pharmaco-vigilance and disposal of drugs at $\mathrm{MCH}$ (Mean, 3.73).

Table 5: Descriptive statistics on Supply Chain Practices

\begin{tabular}{|c|c|c|c|c|c|c|c|}
\hline \multirow[t]{2}{*}{ Item } & \multicolumn{5}{|c|}{ Responses } & \multirow[t]{2}{*}{ Mean } & \multirow{2}{*}{$\begin{array}{l}\text { Std. } \\
\text { Dev }\end{array}$} \\
\hline & $\begin{array}{l}\text { SA } \\
\mathbf{N}(\%)\end{array}$ & $\begin{array}{l}\mathbf{A} \\
\mathrm{N}(\%)\end{array}$ & $\begin{array}{l}\mathbf{N} \\
\mathbf{N}(\%)\end{array}$ & $\begin{array}{l}\mathrm{D} \\
\mathrm{N}(\%)\end{array}$ & $\begin{array}{l}\text { SD } \\
\mathbf{N}(\%)\end{array}$ & & \\
\hline $\begin{array}{l}\text { Supply chain practices (selection, procurement, } \\
\text { distribution and storage) influence EMONC } \\
\text { commodity in MCH in this facility. }\end{array}$ & $27(30)$ & $37(41)$ & $19(21)$ & $2(2)$ & $5(6)$ & 3.88 & 3.50 \\
\hline $\begin{array}{l}\text { MCH staff get involved in selection, procurement, } \\
\text { storage and reporting of health commodities related } \\
\text { with EMONC services in this facility. }\end{array}$ & $10(11)$ & $49(54)$ & $20(22)$ & $9(10$ & $2(2)$ & 3.66 & 3.21 \\
\hline $\begin{array}{l}\text { The procurement method of health commodity } \\
\text { related to EMONC services in this facility. }\end{array}$ & $22(24)$ & $43(48)$ & $13(14)$ & $7(8)$ & $5(6)$ & 3.78 & 3.41 \\
\hline $\begin{array}{l}\text { Health financing on procurement and distribution } \\
\text { of EMONC commodity to Health facilities is } \\
\text { effective. }\end{array}$ & $20(22)$ & $31(34)$ & $21(23)$ & $16(18)$ & $2(2)$ & 3.57 & 3.21 \\
\hline $\begin{array}{l}\text { Facility have policy, guideline and Job aids on } \\
\text { procurement, storage, pharmaco-vigilance and } \\
\text { disposal of drugs at } \mathrm{MCH} \text {. }\end{array}$ & $25(28)$ & $39(43)$ & $10(11)$ & $9(10)$ & $7(8)$ & 3.73 & 3.41 \\
\hline
\end{tabular}

Key: $S A=$ Strongly agreed, $A=$ Agreed, $N=$ Neutral, $D=$ Disagreed, $S D=$ Strongly Disagreed

Results on efficiency in health commodity management are shown in Table 6. Most respondents agreed that the study found out that most of the respondents agreed that they are very particular about the product selection process in their hospital (Mean, 4.04) and healthcare providers get sufficient health commodities of assured quality at competitive prices in accordance with national and international laws. (Mean, 3.81) and they prevent irrational use of supplies by showing users the right way to use the supplies (Mean, 3.89).

Table 6: Efficiency in Health Commodity Management

\begin{tabular}{|c|c|c|c|c|c|c|c|}
\hline \multirow[t]{2}{*}{ Statement } & \multicolumn{5}{|c|}{ Responses } & \multirow[t]{2}{*}{ Mean } & \multirow{2}{*}{$\begin{array}{l}\text { Std. } \\
\text { Dev }\end{array}$} \\
\hline & $\begin{array}{l}\mathbf{S A} \\
\mathbf{N}(\%)\end{array}$ & $\begin{array}{l}\mathbf{A} \\
\mathbf{N}(\%)\end{array}$ & $\begin{array}{l}\mathbf{N} \\
\mathbf{N}(\%)\end{array}$ & $\begin{array}{l}\mathrm{D} \\
\mathrm{N}(\%)\end{array}$ & $\begin{array}{l}\text { SD } \\
\text { N(\%) }\end{array}$ & & \\
\hline $\begin{array}{l}\text { We are very particular about the product } \\
\text { selection process in this hospital. }\end{array}$ & $29(32)$ & $46(51)$ & $9(10)$ & $2(2)$ & $4(4)$ & 4.04 & 3.64 \\
\hline $\begin{array}{l}\text { There is a proper inventory, storage and } \\
\text { distribution system in place. }\end{array}$ & $20(22)$ & $42(47)$ & $14(16)$ & $8(9)$ & $6(7)$ & 3.69 & 3.34 \\
\hline
\end{tabular}




\begin{tabular}{|c|c|c|c|c|c|c|c|}
\hline $\begin{array}{l}\text { We obtain services, supplies, and equipment in } \\
\text { conformance with applicable laws and } \\
\text { regulations. }\end{array}$ & $38(42)$ & $33(37)$ & $9(10)$ & $6(7)$ & $4(4)$ & 4.06 & 3.68 \\
\hline $\begin{array}{l}\text { Healthcare providers get sufficient health } \\
\text { commodities of assured quality at competitive } \\
\text { prices in accordance with national and } \\
\text { international laws. }\end{array}$ & $26(28)$ & $36(40)$ & $13(14)$ & $15(17)$ & $0(0.0)$ & 3.81 & 3.43 \\
\hline $\begin{array}{l}\text { We prevent irrational/incorrect use of supplies } \\
\text { by showing users the right way to use the } \\
\text { supplies. }\end{array}$ & $25(28)$ & $43(48)$ & $13(14)$ & $5(6)$ & $4(4)$ & 3.89 & 3.50 \\
\hline
\end{tabular}

Key: SA=Strongly agreed, $A=$ Agreed, $N=$ Neutral, $D=$ Disagreed, $S D=$ Strongly Disagreed

To determine whether each of the independent variables in this study (logistic management information system, medical staff competency, inventory management, and supply chain management practices) influences the efficient health commodity management in maternal child health, a bivariate linear analysis was carried out as shown Table 7.

Table 7: Bivariate Linear Correlation $\left(\chi^{2}\right)$

\begin{tabular}{llll}
\hline & $\chi^{2}$ & df & P-Value \\
\hline Logistic Management Information System (LMIS) & $4.450^{\mathrm{a}}$ & 1 & 0.035 \\
Staff Competency & $7.048^{\mathrm{a}}$ & 1 & 0.008 \\
Inventory Management & $.000^{\mathrm{a}}$ & 1 & 0.989 \\
Supply Chain management & $.029^{\mathrm{a}}$ & 1 & 0.865 \\
\hline
\end{tabular}

Results indicated that logistic management information system was positively and significantly associated with the efficient health commodity management in $\mathrm{MCH}\left(\chi^{2}=4.450\right.$, $P=0.035)$. This implied that LMIS had a positive and significant association influence on the efficient management of health commodity in MCH services. Medical staff competency was positively and significantly associated with the efficient health commodity management of $\mathrm{MCH}\left(\chi^{2}=7.0489, P=0.008\right)$. However, inventory management and supply chain management practices had no significant influence on efficient management of health commodity in MCH services.

Further multivariate regression analysis between the predictors (logistic management information system, staff competency, inventory management, supply chain practices) of efficient health commodity management was done. See Table 8.
The results showed that the constant was not significant $P=.565$. Results showed that in a combined relationship the logistic management information system had positive and significant influence on the efficient health commodity management $P=.025$. This implies that where is logistic management information system, the management of health commodity for $\mathrm{MCH}$ services is 3.3 times more likely to be efficient than in case where there is no logistic management information system. The regression analysis also revealed a that staff competency $(P=0.005)$ was a significant determinant of efficient health commodity management. Hence, in a combined effect, where there are no competent staff, the management of health commodity is only 0.2 times less likely to be efficient when compared to facilities with competently trained staff. The regression analysis for inventory management and supply chain practices were not significant determinants of efficient health commodity management.

Table 8: Model Summary Multivariate Analysis

\begin{tabular}{|c|c|c|c|c|c|c|c|c|}
\hline & \multirow[b]{2}{*}{ B } & \multirow[b]{2}{*}{ S.E. } & \multirow[b]{2}{*}{ Wald } & \multirow[b]{2}{*}{ df } & \multirow[b]{2}{*}{ Sig. } & \multicolumn{3}{|c|}{$95 \%$ C.I. for $\operatorname{EXP}(B)$} \\
\hline & & & & & & $\operatorname{Exp}(B)$ & Lower & Upper \\
\hline Logistic management in & $\mathrm{n} 1.201$ & .535 & 5.044 & 1 & .025 & 3.322 & 1.165 & 9.474 \\
\hline Staff competency & -1.602 & .569 & 7.917 & 1 & .005 & .202 & .066 & .615 \\
\hline Inventory management & -.533 & .668 & .638 & 1 & .425 & .587 & .159 & 2.171 \\
\hline Supply chain practices & -.290 & .541 & .287 & 1 & .592 & .748 & .259 & 2.160 \\
\hline Constant & .499 & .867 & .331 & 1 & .565 & 1.647 & & \\
\hline
\end{tabular}

a. Variable(s) entered on step 1: logistic management information system, staff competency, inventory management, Supply chain practices 
The Nagelkerke analysis $\left(\mathrm{R}^{2}=0.189\right)$ revealed that the four independent variables; logistic management information system, staff competency, inventory management and supply chain practices contributes to $18.9 \%$ of the change in efficiency of health commodity management in $\mathrm{MCH}$ services.

\section{DISCUSSION}

The respondents disagreed that Logistic Management and Information System affects availability of EMONC commodity. These results agree with previous studies done in Kenya which indicated that the use of healthcare service data and information generated from logistic management information system is not reliable and many public health facilities depend on reporting system that is paper based (Obwocha et al., 2016). The respondents agreed that health financing affects commodity availability. This result is consistent with results of a study done in Nakuru County, Kenya that revealed that inadequate budget negatively affected the availability of the lifesaving $\mathrm{MCH}$ commodities (Wangu and Osuga, 2014). Further results on the influence of facility use LMIS for routine ordering of drugs for health commodities for $\mathrm{MCH}$ were in agreement with a study by Bekele and Anbessa (2021) which found that the availability of drug products relies upon how the LMIS is performing.

The respondents agreed that training and mentorship had an influence on availability of EMONC commodity and this concurred with Pastakia et al., (2018) findings that a reliable and efficient HCM system is dependent on having a workforce that has technical and administrative skills, experience, and capacity to manage effectively. Desale et al., (2013) recommended capacity building for laboratory workforce as a solution for the frequent shortages of laboratory commodities in health facilities in Ethiopia.

In view of inventory management, the respondents were on agreement that inventory management affects efficient health commodity management in child health in Meru County. The findings are consistent with Bray and Awuah (2019) who found out that inventory management is critical to the function of commodity management, because without proper inventory systems, bullwhip effect is likely to occur and impede health service delivery.

The study showed that quality of health commodity should be in tandem with the national and international laws and standards as supported by (Tsofa et al., 2017), who said that any facility that performs inventory internal control of health commodity by use of requisition orders for tracking, inventory physical counts is evidence of experiences for internal controls. Inefficiencies in internal controls systems have been cited as reasons for causing major and late request for commodities thus leading to shortage of important health products in health facilities.

\section{CONCLUSION}

Logistical management information system and medical staff competency statistically and significantly influence efficient health commodity management in $\mathrm{MCH}$ services. An improvement LMIS and staff competency will positively improve the efficient management of health commodity. The study recommends the County Health Department of Meru should i) invest in health information systems for quantification, forecasting reporting and procurement of medical goods and equipment; ii) conduct continuous professional education among health workers to ensure efficient management of healthcare commodities in the health facilities.

\section{Competing interests}

There are no competing interests to declare.

\section{Authors Contributions}

All authors contributed to study design and data analysis and interpretation. The authors have contributed in drafting the manuscript and have approved the final version of the publication.

\section{REFERENCES}

[1] Bekele, A., \& Anbessa, G. T. (2021). Logistics Management Information System Performance of Program Medicines in Public Health Facilities of East Gojjam Zone, Northwest Ethiopia: A Cross-Sectional Study. Journal of Multidisciplinary Healthcare, 14, 81.

[2] Bray, A. V., \& Awuah, S. O. (2019 ). Distribution Challenges Of Health Commodities. 9th International Conference on Operations and Supply Chain Management, Vietnam.

[3] Cohen, J., Govindaraj, R., \& Reich, M. (2000). Discussion Paper; World Bank Pharmaceuticals. Geneva,Switzerland: Worlbank.

[4] Damtew, D., Worku, F., Tesfaye, Y., \& Jemal, A. (2019). Availability of Lifesaving Maternal and Child Health Commodities and Associated Factors in Public and Private Health Facilities of Addis Ababa, Ethiopia. Health services research and managerial epidemiology, 6, 2333392819892350.

[5] Desale, A., Taye, B., Belay, G., \& Nigatu, A. (2013). Assessment of laboratory logistics management information system practice for HIV/AIDS and tuberculosis laboratory commodities in selected public health facilities in Addis Ababa, Ethiopia. Pan African Medical Journal, 15(1).

[6] Ibegbunam, I., \& McGill, D. (2012). Health commodities management system: priorities and challenges. Journal of Humanitarian Logistics and Supply Chain Management., Vol. 2 Iss 2 pp. 161 - 182.

[7] KDHS. (2014): Kenya Demographic Health Survey Report

[8] Ministry of Health. (2014). The Kenya Health Policy 2014 - 2030; Towards attaining the highest standard of health. Nairobi: Ministry of Health.

[9] Ministry of Health. (2015). The Kenya Health Facilities Distribution Data Sheets Nairobi: Ministry of Health.

[10] Obwocha W, Ayodo G, Nyangura A, Thomas O. (2016). Utilization of healthcare information among health Care Workers in Gucha Subcounty, Kisii County, Kenya. J Heal Educ Res. 04(04):192. https://doi.org/10.4172/2380-5439.

[11] Owino B, Ruto D \& Mureithi Z. (2014) "Scaling up Health Facilities' Readiness to Provide Emergency Obstetric and Newborn Care Services, Meru County"

[12] Pastakia, S. D., Tran, D. N., Manji, I., Wells, C., Kinderknecht, K., \& Ferris, R. (2018). Building reliable supply chains for noncommunicable disease commodities: lessons learned from HIV and evidence needs. Aids (supp.), 32, S55-S61.

[13] Tola, F. B., Anbessa, G. T., \& Yikna, B. B. (2020). Anti-Tuberculosis Commodities Management Performance and Factors Affecting It at Public Health Facilities in Dire Dawa City Administration, Ethiopia. Journal of Multidisciplinary Healthcare, 13, 1677.

[14] Transition Authority. (2014). Assessment of the uptake of devolved health functions in level five hospitals. Nairobi, Kenya: Transition Authority. 
[15] Tsofa, B., Goodman, C., Gilson, L., \& Molyneux, S. (2017). Devolution and its effects on health workforce and commodities management-early implementation experiences in Kilifi County, Kenya. International journal for equity in health, 16(1), 1-13.

[16] United Nations Children's Fund by JSI. (2015). Quantification of Health Commodities: RMNCH Supplement. Arlington, VA: JSI Research \& Training Institute Inc; 2015.

[17] United Nations Development Program. (2003). Annual Report. Kampala: UNDP.

[18] Wangu, M. M., \& Osuga, B. O. (2014). Availability of essential medicines in public hospitals: A study of selected public hospitals in Nakuru County, Kenya. African Journal of Pharmacy and Pharmacology, 8(17), 438-442.

[19] WHO. (2014). Medicines in Health Systems - Advancing access, affordability and appropriate use. Geneva

[20] World Health Organization. (2010). Health Systems Financing, The Path to Universal Coverage. Geneva, Switzerland: WHO.
[21] Yamane, T. (1967). Statistics: an introductory analysis, 2nd ed., Harper and Row, New York.

\section{AUTHORS}

First Author - Elvis Mwandawiro Mbatia, Department of Health Systems Management, Kenya Methodist University Second Author - Eunice Muthoni Mwangi, Department of Health Systems Management, Kenya Methodist University Third Author - Wanja Mwaura-Tenambergen, Department of Health Systems Management, Kenya Methodist University

Correspondence email: mwandawiro222@yahoo.com 